\title{
A prospective study of gout in New Zealand Maoris
}

\author{
GERHARD W. BRAUER AND IAN A. M. PRIOR \\ From the Epidemiology Unit, Wellington Hospital, Wellington, New Zealand
}

SUMMARY Results are reported from the first prospective study of gout in New Zealand Maoris based on a sample of 388 males and 378 females. At baseline, high mean levels of serum uric acel (SUA) were found, $0.422 \pm 0.092 \mathrm{mmol} / 1(7.05 \pm 1.54 \mathrm{mg} / 100 \mathrm{ml})$ in males and 0.350 $\pm 0.0 \% 1$ $\mathrm{mmol} / 1(5 \cdot 85 \pm 1 \cdot 52 \mathrm{mg} / 100 \mathrm{ml})$ in females. On the basis of traditional criteria (SUA above 0.42 $\mathrm{mmol} / 1(7.0 \mathrm{mg} / 100 \mathrm{ml})$ in males and above $0.36 \mathrm{mmol} / 1(6.0 \mathrm{mg} / 100 \mathrm{ml})$ in females) the prevalenoe of hyperuricaemia was $49 \%$ in males and $42 \%$ in females. The baseline prevalence of gout $(8 \cdot 8 \%$ for males and $0.8 \%$ for females) and the subsequent 11 -year incidence rates $(10.3 \%$ for males ang $4.3 \%$ for females) are discussed in relation to specified SUA classes. When traditional, sex-speciffc criteria for hyperuricaemia were used, no relationship was found between the prevalence of hyperuricaemia and the incidence of gout. There was, however, a sharp increase in the incidence rate of gout in both sexes when SUA levels were above $0.48 \mathrm{mmol} / 1(8.0 \mathrm{mg} / 100 \mathrm{ml})$. In subjects witho్ baseline SUA above this level, the age-standardised 11-year incidence rate of gout was $29 \cdot 1 \%$ for males and $37 \cdot 2 \%$ for females. A previously unreported relationship linking muscle size to the incidence of gout in males is presented as a major finding of the study. Other risk factors associated with gout were body mass and blood pressure.

New Zealand Maoris have high levels of serum uric acid (SUA) and are at high risk for gout (Lennane et al., 1960; Prior, 1962; Prior and Rose, 1966; Prior et al., 1966; Rose et al., 1966). This paper presents the results of the first prospective epidemiological study of gout and its risk factors in this population, made possible by the recent completion of a longitudinal data base encompassing 3 consecutive epidemiological surveys of a group of New Zealand Maoris: rounds I (1962/63), II (1968/69), and III (1974). Findings consist of (a) a summary of baseline (round $\mathrm{n}$ ) data, including the distribution of SUA, age and sex effects on SUA, and ine baseline prevalence of gout; and (b) the incidence study (between baseline at round I and the follow-up at round III), in which evidence is presented of a relationship in males between muscle size and the incidence of gout.

\section{Methods}

WHO Special Committee recommendations on methodology were followed in most instances. A full description has been previously published (Prior, 1962; Prior et al., 1966). Serum cholesterol was estimated by the method of Abell et al. (1952) and SUA by a non-enzymatic colorimetric technique correlating closely with uricase methods (Buchan et al., 1965). Traditional SUA cut-off values abope which subjects were considered hyperuricaemic ame $0.42 \mathrm{mmol} / 1(7.0 \mathrm{mg} / 100 \mathrm{ml})$ for males and 0.36 $\mathrm{mmol} / 1(6.0 \mathrm{mg} / 100 \mathrm{ml})$ for females subjects.*

Earlier publications using these data based diagnosis of gout on the presence of hyperuricaemia (unless the subject was on uricosuric therapy), plifs one or more attacks of typical podagra affecting the joints of the great toe or foot. However, in this prospective study of the risk factors for gout it whs considered desirable that a diagnosis of gout be independent of the SUA level, thus allowing stu和 of the latter as a risk factor. Furthermore, in a recemt study, Snaith and Coomes (1977) illustrate tre possibility of gout occurring at relatively low SU levels and this, plus the problem of classifying subjects who may have been on urate-lowering medocation, suggested that the diagnostic use of Suf level be avoided. Consequently, for diagnosis Of clinical gout, a medical history of two or more typical attacks of podagra affecting the great toe was required.

* For conversion from SI to traditional units, the follow苚 factors apply: SUA, $\mathrm{mg} / 100 \mathrm{ml}=\mathrm{mmol} / \mathrm{l} \times 16.72$; sermm cholesterol, $\mathrm{mg} / 100 \mathrm{ml}=\mathrm{mmol} / 1 \times 38 \cdot 61$. Both SI and traditional units are provided in the text. 
In order to take into account the effect of time on the manifestations of a chronic disease such as gout, $Z$-score transformations were used in the final analyses. This removed the effect of age on continuous variables which are thus expressed in standard deviation units. Student's $t$ test was used to test for the significance of differences between means. Multivariate discriminant analysis was used to select sets of variables capable of discriminating 2 groups (gouty and gout-free) by step-wise entry of variables into a function which maximises a generalised distance measure, in this case Mahalanobis' $D^{2}$. Associations between continuous variables are described by Pearson and partial correlations. Gout prevalence and incidence rates were agestandardised (indirect method) to take into account differing age structures of subgroups and to thus allow comparisons between SUA classes and between males and females.

Total body mass was estimated by a body mass index (BMI), weight $/$ height $^{2}\left(\mathrm{~g} / \mathrm{cm}^{2}\right)$. Following Jellife (1966), upper arm muscle circumference was estimated by upper arm circumference $(\mathrm{cm})-\pi \times$ triceps skinfold thickness $(\mathrm{cm})$. The use of the latter variable as an indicator of body composition is discussed by Frisancho (1974).

\section{Results}

\section{POPULATION}

The age and sex characteristics of the $\mathbf{3 8 8}$ males and 378 females examined at baseline and their follow-up status 11 years later are given in Table 1. Details of the baseline population samples have been previously published (Prior, 1962; Prior, et al., 1966),

Table 1 Age and sex characteristics of subjects seen at the baseline examination and their status at follow-up

\begin{tabular}{lcccc}
\hline & Baseline & \multicolumn{3}{l}{ Follow up survey } \\
\cline { 2 - 5 } Age & No. & Deceased & $\begin{array}{c}\text { Lost to } \\
\text { follow up }\end{array}$ & Seen \\
\hline Males & & & & \\
15-24 & & & & \\
$25-34$ & 56 & 3 & 8 & 45 \\
$35-44$ & 92 & 5 & 5 & 82 \\
$45-54$ & 66 & 7 & 1 & 58 \\
$55-64$ & 90 & 28 & 6 & 56 \\
$65-74$ & 53 & 28 & 0 & 25 \\
$75+$ & 18 & 13 & 0 & 5 \\
Total & 13 & 12 & 0 & 1 \\
& 388 & 96 & 20 & 272 \\
Females & & & & \\
$15-24$ & & & & \\
$25-34$ & 57 & 1 & 6 & 50 \\
$35-44$ & 81 & 4 & 7 & 70 \\
$45-54$ & 84 & 10 & 6 & 68 \\
$55-64$ & 73 & 11 & 2 & 60 \\
$65-74$ & 48 & 24 & 0 & 24 \\
$75+$ & 25 & 20 & 0 & 5 \\
Total & 10 & 7 & 0 & 3 \\
\hline & 378 & 77 & 21 & 280 \\
\hline
\end{tabular}

Female subjects pregnant at baseline were excluded from the incidence study.

The population at risk for gout at baseline includes 96 males and 77 females who subsequently died, as well as $\mathbf{2 0}$ males and $\mathbf{2 1}$ females who were otherwise lost to follow-up; these 2 groups were therefore compared, on the basis of baseline variables with the subjects who were seen at the follow-up survey. Apart from an anticipated age difference, for which some continuous variables were adjusted by means of Z-score transformation, no baseline differences were found between those subjects seen at the follow-up examination and those who died after the baseline survey. Those subjects lost to follow-up were slightly younger than the resurveyed subjects (males: $t_{290}=2 \cdot 14, P=0.033$; females: $t_{299}=2.47$, $P=0.014)$; and in males this group had a lower mean cholesterol $\left(t_{28}=3.89, P<0.001\right)$. This indicated that mortality and other reasons for dropping out of the study have not adversely affected the assumption that the 'survivor' group was representative of the baseline population at risk for gout. Incomplete data for some subjects have resulted in minor discrepancies between some totals presented in the text and in tables, depending on the variables concerned.

\section{BASELINE DATA}

The baseline distribution of SUA values by sex and the mean values by age and sex are shown in Figs. 1 and 2. These distributions are similar to those reported by Hall et al. (1967) for the Framingham population, Mikkelsen et al., (1965) for the Tecumseh

Table 2 Baseline SUA levels and the frequency of hyperuricaemia within age groups

\begin{tabular}{|c|c|c|c|}
\hline \multirow{2}{*}{ Age (years) } & \multirow{2}{*}{ No. } & $S U A(\mathrm{mmol} / \mathrm{l})$ & $\begin{array}{l}\text { Frequency of } \\
\text { hyperuricaemia }\end{array}$ \\
\hline & & Mean (SE) & No. $(\%)$ \\
\hline $\begin{array}{l}\text { Males } \\
15-24 \\
25-34 \\
35-44 \\
45-54 \\
55-64 \\
65-74 \\
75+ \\
\text { Total }\end{array}$ & $\begin{array}{r}55 \\
90 \\
66 \\
89 \\
53 \\
18 \\
13 \\
384\end{array}$ & $\begin{array}{l}0.411(0.011) \\
0.415(0.008) \\
0.439(0.011) \\
0.420(0.011) \\
0.442(0.016) \\
0.389(0.019) \\
0.400(0.014) \\
0.422\end{array}$ & $\begin{array}{c}U A>0.42 \mathrm{mmol} / \mathrm{l}) \\
26(47) \\
47(52) \\
34(52) \\
41(46) \\
28(53) \\
5(28) \\
7(54) \\
188(49)\end{array}$ \\
\hline $\begin{array}{l}\text { Females } \\
15-24 \\
25-34 \\
35-44 \\
45-54 \\
55-64 \\
65-74 \\
75+ \\
\text { Total }\end{array}$ & $\begin{array}{r}56 \\
81 \\
83 \\
73 \\
48 \\
25 \\
10 \\
376\end{array}$ & $\begin{array}{l}0.335(0.011) \\
0.327(0.010) \\
0.346(0.010) \\
0.349(0.010) \\
0.393(0.015) \\
0.389(0.023) \\
0.355(0.014) \\
0.350\end{array}$ & $\begin{array}{c}U A>0.36 \mathrm{mmol} / l) \\
15(27) \\
27(33) \\
35(42) \\
29(40) \\
32(67) \\
15(60) \\
6(60) \\
159(42)\end{array}$ \\
\hline
\end{tabular}


study, and Sturge et al. (1977) for a non-random sample of adults in England and Scotland, with the difference that the Maori values are higher overall by about $0 \cdot 10 \mathrm{mmol} / 1(2 \mathrm{mg} / 100 \mathrm{ml})$.

Regression analyses revealed a positive linear relationship between age and SUA in female subjects. To remove any such age-effect as well as to counteract the skewness of the SUA distributions, Z-score transformations of SUA values were used in the incidence study. On the traditional basis of 0.42 and $0.36 \mathrm{mmol} / 1(7.0$ and $6.0 \mathrm{mg} / 100 \mathrm{ml})$ as the SUA cut-off values for hyperuricaemia, ़ำ males and females, respectively, the prevalence $=$ of hyperuricaemia at baseline is $49 \%$ in males and $4 \overline{2} \%$ in females (Table 2).

Of the 388 males and 378 non-pregnant fema examined at baseline, 34 males and 3 females wore diagnosed as having gout, a prevalence of $8.8 \%$ and $0.8 \%$, respectively. Since the small numbers of the latter group preclude statistical analysis, the only cross-sectional differences shown are those between gouty and non-gouty males (Table 3 ).
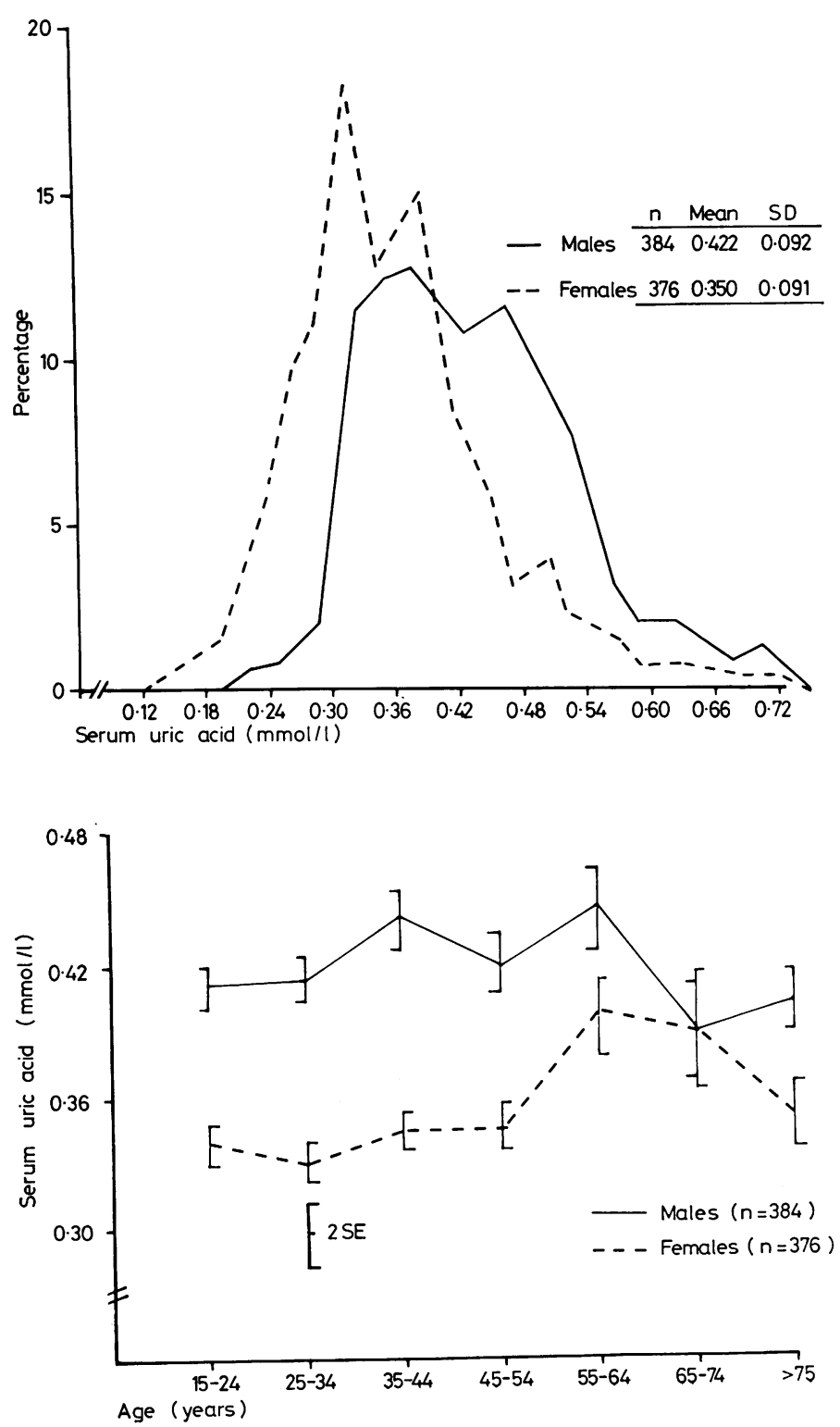

Fig. 1 Distribution of serum uric ackd values. Maori round I (baseline).

Fig. 2 Age-sex specific mean serum $\widetilde{N}_{\text {ic }}$ ic acid. Maori round I (baseline). 
Table 3 Gout prevalence: baseline comparisons of gouty and non-gouty males

\begin{tabular}{|c|c|c|c|c|}
\hline & Gouty $(n=34)$ & Non-gouty $(n=354)$ & & \\
\hline & Mean $(S E)$ & Mean $(S E)$ & $t$ & $\boldsymbol{P}$ \\
\hline $\begin{array}{l}\text { Age (years) } \\
\text { Weight (kg) } \\
\text { Upper arm circumference (cm) } \\
\text { Triceps skinfold (mm) } \\
\text { Muscle circumference }(\mathrm{cm}) \\
\text { Subscapular skinfold }(\mathrm{mm}) \\
\text { Systolic blood pressure }(\mathrm{mmHg}) \\
\text { Diastolic blood pressure }(\mathrm{mmHg}) \\
\text { Body mass index } \\
\text { SUA (mmol/l) } \\
\text { Serum cholesterol (mmol/l) }\end{array}$ & $\begin{array}{l}51 \cdot 8(1 \cdot 1) \\
90.9(2.9) \\
32 \cdot 7(0.4) \\
13 \cdot 0(0.9) \\
28 \cdot 7(0.4) \\
18.0(1 \cdot 0) \\
154.4(4 \cdot 7) \\
98 \cdot 1(2 \cdot 3) \\
3.11(0.08) \\
0.512(0.021) \\
6.434(0.303)\end{array}$ & $\begin{array}{l}41.4(0.9) \\
79.0(0.8) \\
30.3(0.2) \\
11.0(0.2) \\
26.8(0.2) \\
14.2(0.4) \\
134.0(1.1) \\
86.8(0.6) \\
2.72(0.03) \\
0.413(0.004) \\
5.555(0.061)\end{array}$ & $\begin{array}{l}7 \cdot 54 \\
4 \cdot 22 \\
5 \cdot 16 \\
2 \cdot 49 \\
3 \cdot 49 \\
2 \cdot 89 \\
4 \cdot 28 \\
5 \cdot 17 \\
4 \cdot 47 \\
4 \cdot 68 \\
2 \cdot 84\end{array}$ & $\begin{array}{r}<0.001 \\
<0.001 \\
<0.001 \\
0.013 \\
0.001 \\
0.004 \\
<0.001 \\
<0.001 \\
<0.001 \\
<0.001 \\
0.007\end{array}$ \\
\hline
\end{tabular}

Conversion : traditional to SI units - systolic and diastolic blood pressure: $1 \mathrm{mmHg} \approx 0.133 \mathrm{kPa}$.

Conversion: SI to traditional units - cholesterol: $1 \mathrm{mg} / 100 \mathrm{ml} \approx 0.0259 \mathrm{mmol} / 1$.

The age-standardised prevalence of gout in males, within SUA classes at baseline, is shown in Table 4. On the basis of relative risk of gout in male Maoris a SUA discrimination value (Sunderman, 1975) for hyperuricaemia] of $0.48 \mathrm{mmol} / 1(8.0 \mathrm{mg} / 100 \mathrm{ml})$ would be more useful than $0.42 \mathrm{mmol} / 1(7.0 \mathrm{mg} /$ $100 \mathrm{ml})$.

\section{INCIDENCE OF GOUT}

The incidence study was based on 252 males and 279 females who did not suffer from gout at the baseline examination and who were re-examined eleven years later; a response rate of $90 \%$ of eligible subjects. Comparisons were made (within each sex) between those subjects who remained free of the disease and those who at the follow up examination reported having had recurrent attacks of gout. Twenty-six males and 12 females reported recurrent podagra affecting the great toe, an incidence of $10.3 \%$ and $4.3 \%$ in males and females, respectively. The age-standardised attack rate and relative risk of gout within SUA classes is examined in Table 5.

\section{RISK FACTORS CONTRIBUTING TO GOUT}

Those subjects with and those without subsequent gout were compared on the basis of their baseline variables (Table 6). Risk factors for gout common to both males and females were found to be weight,

Table 4 Age-standardised prevalence of gout in males by baseline $S U A$ classes*

\begin{tabular}{llll}
\hline $\begin{array}{l}\text { SUA classes } \\
(\text { mmol/l) }\end{array}$ & $\begin{array}{l}\text { Age- } \\
\text { standardised } \\
\text { prevalence } \\
\text { No. (per hundred) }\end{array}$ & $\begin{array}{l}\text { Cases } \\
\text { of gout }\end{array}$ & $\begin{array}{l}\text { Risk relative } \\
\text { to prevalence } \\
\text { below } 0.42 \\
\text { mmol/l }\end{array}$ \\
\hline Less than 0.42 & $200(4.48)$ & 9 & \\
0.42 or more & $188(13.36)$ & 25 & 2.98 \\
0.48 or more & $102(18.84)$ & 23 & 4.55 \\
0.54 or more & $40(21.49)$ & 13 & 4.80 \\
\hline
\end{tabular}

*Indirect standardisation was used with the pooled male sample as reference population.
BMI, blood pressure, and SUA. Age was a risk factor in females, reflecting the effect of age on SUA; although cross-sectionally the age difference between gouty and non-gouty males (see Table 3 ) was what would be expected in a chronic disease, these groups did not differ significantly for age in the incidence study. In both the cross-sectional and prospective analyses upper arm muscle circumference was greater in gouty males; the difference in females was not significant. Subcutaneous fat and serum cholesterol, greater in gouty than in non-gouty males cross-sectionally, were not risk factors for the incidence of gout.

In addition to univariate analyses to determine individual risk factors, step-wise discriminant analysis was undertaken to find the statistically 'best' set of baseline variables which would discriminate between those subjects who developed

Table 5 Age-standardised incidence and relative risk of gout, within baseline SUA classes, in males and females over the 11-year period between baseline and follow-up*

\begin{tabular}{|c|c|c|c|c|}
\hline & \multicolumn{4}{|c|}{ SUA classes ( $\mathrm{mmol} / \mathrm{l})$} \\
\hline & $\begin{array}{l}A \\
<0.36\end{array}$ & $\begin{array}{l}B \\
0.36-0.48\end{array}$ & $\begin{array}{l}C \\
>0.48\end{array}$ & Total \\
\hline $\begin{array}{l}\text { Males } \\
\text { No. at risk } \\
\text { New gout cases } \\
\text { Incidence }\end{array}$ & $\begin{array}{r}69 \\
2\end{array}$ & $\begin{array}{r}125 \\
7\end{array}$ & $\begin{array}{l}56 \\
17\end{array}$ & $\begin{array}{r}252 \\
26\end{array}$ \\
\hline $\begin{array}{l}\text { Crude } \\
\text { Age-standardised } \\
\text { Risk relative to }\end{array}$ & $\begin{array}{l}2.9 \% \\
2.8 \%\end{array}$ & $\begin{array}{l}5.6 \% \\
5.7 \%\end{array}$ & $\begin{array}{l}30.6 \% \\
29.1 \%\end{array}$ & $\begin{array}{c}10 \cdot 3 \% \\
-\end{array}$ \\
\hline class $\mathbf{A}$ & - & $2 \cdot 0$ & $10.4 \%$ & - \\
\hline $\begin{array}{l}\text { Females } \\
\text { No. at risk } \\
\text { New gout cases } \\
\text { Incidence }\end{array}$ & $\begin{array}{r}169 \\
1\end{array}$ & $\begin{array}{r}88 \\
3\end{array}$ & $\begin{array}{r}22 \\
8\end{array}$ & $\begin{array}{r}279 \\
12\end{array}$ \\
\hline $\begin{array}{l}\text { Crude } \\
\text { Age-standardised } \\
\text { Risk relative to }\end{array}$ & $\begin{array}{l}0.6 \% \\
0.6 \%\end{array}$ & $\begin{array}{l}3.4 \% \\
3.1 \%\end{array}$ & $\begin{array}{l}36.4 \% \\
37 \cdot 2 \%\end{array}$ & $\begin{array}{c}4 \cdot 3 \% \\
-\end{array}$ \\
\hline class $\mathbf{A}$ & - & $5 \cdot 2$ & $62 \cdot 0$ & - \\
\hline
\end{tabular}

*Indirect standardisation was used with the pooled 'at risk' group as the reference population. 
Table 6 Gout incidence: baseline comparisons between those subjects with and those without subsequent gout

\begin{tabular}{|c|c|c|c|c|}
\hline & \multicolumn{2}{|c|}{ Gout subsequent to baseline } & \multirow[b]{3}{*}{$t$} & \multirow[b]{3}{*}{$\boldsymbol{P}$} \\
\hline & \multirow{2}{*}{$\frac{\text { Yes }}{\text { Mean (SE) }}$} & \multirow{2}{*}{$\frac{\text { No }}{\operatorname{Mean}(S E)}$} & & \\
\hline & & & & \\
\hline $\begin{array}{l}\text { Males } \\
\text { Age (years) } \\
\text { Weight (kg) } \\
\text { Upper arm circumference (cm) } \\
\text { Triceps skinfold (mm) } \\
\text { Muscle circumference (cm) } \\
\text { Muscle circumference Z-score } \\
\text { Subscapular skinfold (mm) } \\
\text { Systolic blood pressure (mmHg) } \\
\text { Diastolic blood pressure (mmHg) } \\
\text { Diastolic blood pressure Z-score } \\
\text { Body mass index } \\
\text { SUA (mmol/l) } \\
\text { SUA Z-score } \\
\text { Serum cholesterol (mmol/l) }\end{array}$ & $\begin{array}{l}n=26 \\
38.6(1 \cdot 9) \\
91 \cdot 8(3 \cdot 8) \\
32.9(0 \cdot 7) \\
10 \cdot 7(0 \cdot 6) \\
29.2(0 \cdot 5) \\
0.65(0 \cdot 16) \\
16 \cdot 7(1 \cdot 4) \\
141.4(3 \cdot 7) \\
95 \cdot 0(2 \cdot 0) \\
0.54(0 \cdot 17) \\
3.09(0 \cdot 11) \\
0.486(0.016) \\
0.69(0 \cdot 19) \\
5.818(0.296)\end{array}$ & $\begin{array}{c}n=226 \\
36.9(0.9) \\
78 \cdot 2(0.9) \\
30.3(0.2) \\
11.0(0.3) \\
26.9(0.2) \\
-0.11(0.06) \\
14.0(0.5) \\
130.8(1 \cdot 0) \\
85.6(0.7) \\
-0.09(0.06) \\
2.69(0.03) \\
0.404(0.005) \\
-0.26(0.07) \\
5.631(0.072)\end{array}$ & $\begin{array}{l}0 \cdot 82 \\
3 \cdot 52 \\
3 \cdot 83 \\
0 \cdot 43 \\
4 \cdot 31 \\
3 \cdot 93 \\
1 \cdot 88 \\
3 \cdot 19 \\
4 \cdot 06 \\
3 \cdot 31 \\
4 \cdot 19 \\
5 \cdot 10 \\
4 \cdot 33 \\
0 \cdot 61\end{array}$ & $\begin{array}{l}\text { NS } \\
0.001 \\
0.001 \\
\text { NS } \\
0.001 \\
0.001 \\
\text { NS } \\
0.002 \\
0.001 \\
0.001 \\
0.001 \\
0.001 \\
0.001 \\
\text { NS }\end{array}$ \\
\hline $\begin{array}{l}\text { Females } \\
\text { Age (years) } \\
\text { Weight (kg) } \\
\text { Upper arm circumference (cm) } \\
\text { Triceps skinfold (mm) } \\
\text { Muscle circumference (cm) } \\
\text { Muscle circumference Z-score } \\
\text { Subscapular skinfold (mm) } \\
\text { Systolic blood pressure (mmHg) } \\
\text { Diastolic blood pressure (mmHg) } \\
\text { Diastolic blood pressure Z-score } \\
\text { Body mass index } \\
\text { SUA (mmol/1) } \\
\text { SUA Z-score } \\
\text { Serum cholesterol (mmol/l) }\end{array}$ & $\begin{array}{l}n=12 \\
46 \cdot 3(3 \cdot 3) \\
83 \cdot 4(6 \cdot 7) \\
30 \cdot 8(1 \cdot 2) \\
20 \cdot 8(2 \cdot 9) \\
24 \cdot 2(0 \cdot 8) \\
0.34(0 \cdot 33) \\
25 \cdot 9(3 \cdot 7) \\
165 \cdot 2(11 \cdot 6) \\
106 \cdot 9(5 \cdot 0) \\
1.03(0 \cdot 40) \\
3 \cdot 27(0 \cdot 23) \\
0 \cdot 474(0 \cdot 023) \\
1 \cdot 38(0 \cdot 27) \\
5.463(0 \cdot 301))\end{array}$ & $\begin{array}{l}n=267 \\
38.0(0.8) \\
72.0(1 \cdot 0) \\
29 \cdot 1(0 \cdot 3) \\
19.8(0.5) \\
22.9(0 \cdot 1) \\
-0.04(0.06) \\
21 \cdot 5(0.6) \\
135.9(1 \cdot 7) \\
87.0(0.9) \\
-0.09(0.06) \\
2.86(0.04) \\
0.337(0.005) \\
-0.10(0.06) \\
5.391(0.064)\end{array}$ & $\begin{array}{l}2 \cdot 10 \\
2 \cdot 34 \\
1 \cdot 35 \\
0 \cdot 42 \\
1 \cdot 92 \\
1 \cdot 39 \\
1 \cdot 42 \\
2 \cdot 51 \\
4 \cdot 56 \\
2 \cdot 73 \\
2 \cdot 11 \\
5 \cdot 81 \\
5 \cdot 25 \\
0 \cdot 23\end{array}$ & $\begin{array}{c}0.037 \\
0.020 \\
\text { NS } \\
\text { NS } \\
\text { NS } \\
\text { NS } \\
\text { NS } \\
0.029 \\
0.001 \\
0.019 \\
0.036 \\
0.001 \\
0.001 \\
\text { NS }\end{array}$ \\
\hline
\end{tabular}

gout between examinations and those who remained gout-free. In females SUA Z-scores alone provided the best separation and further multivariate analysis was not appropriate. In males, SUA and muscle size, age-adjusted by $\mathrm{Z}$-score transformation, together provided the best discrimination between the two groups (Table 7).

\section{Discussion}

The high prevalence of gout in New Zealand Maoris has now been supported by a study of incidence

Table 7 Ability of a discriminant function of baseline SUA and muscle size (adjusted for age) to correctly classify subsequent cases of gout and non-gout in males*

\begin{tabular}{llc}
\hline Actual group & \multicolumn{2}{l}{ Predicted group membership } \\
\cline { 2 - 3 } & Group 1 & Group 2 \\
\hline $\begin{array}{l}\text { Group 1 }(\mathrm{n}=25) \\
\begin{array}{l}\text { New gout cases at } \\
\text { follow up) }\end{array}\end{array}$ & $18(72 \cdot 0 \%)$ & $7(28.0 \%)$ \\
$\begin{array}{l}\text { Group 2 }(\mathrm{n}=221) \\
\text { (Non-gout at both } \\
\text { examinations) }\end{array}$ & $64(29.0 \%)$ & $157(71.0 \%)$ \\
\hline
\end{tabular}

*Percentage of male subjects correctly classified $=71 \cdot 1 \%$. cases over an 11-year period. The development of a number of new cases in both males and females $\overrightarrow{\text { mas }}$ allowed some predictive factors to be determinêd. As would be expected, SUA level was the mast important predictor. In subjects with levels above $0.48 \mathrm{mmol} / 1(8.0 \mathrm{mg} / 100 \mathrm{ml})$ the attack rate $20 \mathrm{f}$ gout over the 11 -year period was $29.1 \%$ in mafes and $37.2 \%$ in females. This represents a 5 - and $\mathbf{1 0 -}$ fold increase respectively, of the risk of subsequent gout relative to the next lower SUA class, $0 \cdot$. 16 $0.48 \mathrm{mmol} / 1(6.0-8.0 \mathrm{mg} / 100 \mathrm{ml})$. These findipgs have important implications for the determination of a discrimination value for hyperuricaemia in Maoris, both male and female, and support the suggestion (Rose et al. (1966) that a single St?A level of $0.48 \mathrm{mmol} / 1(8.0 \mathrm{mg} / 100 \mathrm{ml})$ would be a more useful cut-off level than the traditional sexspecific values. On the Use of this single reference value could provide a more effective basis for intervention programmes. If used with these data, the higher cut-off results in considerably reduced baseline prevalences of hyperuricaemia $(26.8 \%$ in males and $10 \cdot 1 \%$ in females) which then parałel very closely the likelihood of developing gout $(10.3 \%$ in males and $4.3 \%$ in females).

One of the striking findings in this long term stifay has been the high incidence rate of gout, $37 \%$ ofer 
the 11-year period, in females with SUA above $0.48 \mathrm{mmol} / 1(8.0 \mathrm{mg} / 100 \mathrm{ml})$. This suggests that the occurrence of clinical gout is dependent to a much greater extent on SUA levels than on sex or other possible precipitating factors. In the majority of populations the number at risk will be extremely small. The Polynesian predisposition to hyperuricaemia, however, sets them apart and places them in the higher risk category.

A relationship between muscle size and the incidence of gout does not appear to be referred to in the literature and is presented as a major finding of this study. The purine-rich nature of muscle tissue suggests one reason why this variable might be implicated, although the correlation between SUA and muscle size $(\mathrm{r}=0.237, \mathrm{P}=0.001)$ disappeared when correlated for BMI $(\mathrm{r}=0.010, \mathrm{P}=0.86)$. Sturge et al. (1977) reported that lean body mass (LBM) was positively correlated with SUA in both sexes, but when entered into step-wise regression together with a measure of total body mass (ponderal index) LBM in males no longer explained a significant amount of SUA variation. A correlation between SUA and LBM $\left(t_{55}=6.34 \mathrm{P}<0.001\right)$ has been reported by Kennedy et al. (1975); this result is based on a pooled group of 27 males and 30 females and a sex difference in the effect of LBM on SUA is not reported.

Further evidence that muscularity, in Caucasian males, does not seem to be accompanied by elevated SUA has been reported by Gertler et al. (1951). In a study of the relationship between SUA and physique, using Sheldon's somatotype approach (Sheldon et al., 1940) a clear correlation was shown with endomorphy (a measure of obesity), but only an equivocal relationship with mesomorphy (a measure of muscularity). Sheldon and his co-workers conclude that 'though it was expected that the muscle mass of the mesomorphs would contribute to their SUA, the dominant mesomorphs did not differ appreciably from the mid-range physiques, thus confirming the lack of correlation between mesomorphy and uric acid'.

The finding of the present study is thus taken as evidence for the existence of a factor in muscle size which is involved in the pathogenesis of gout but which does not seem to be involved by way of elevating SUA. More research is now needed to corroborate and investigate muscle size as a risk factor for gout.

The characteristics of gouty versus non-gouty males in both the cross-sectional and the longitudinal analyses certainly highlight their higher blood pressure, greater body mass, greater muscle size, and higher SUA levels. This study now gives some more definite leads towards the prevention of the long-term effects of hyperuricaemia and clinical gout by active intervention in high risk subjects, ie, males and females with SUA levels above $0.48 \mathrm{mmol} / 1$ $(8.0 \mathrm{mg} / 100 \mathrm{ml})$, and particularly males who have both a high SUA level and a large upper arm muscle circumference.

There is still much to be learned concerning uric acid metabolism and gout in Polynesian people. Recent work by Campion et al. (1975) has established that Maoris, both gouty subjects and asymptomatic hyperuricaemics, were capable of binding more sodium urate than Caucasian gouty or hyperuricaemic subjects. This involved binding to albumin but the Maoris also had urate bound to globulins which had not been shown in Caucasians. This indicates a clear abnormality of urate binding and these studies need to be carried further to determine more clearly what part urate binding plays in the differences in SUA levels within and between different Polynesian populations.

A comparison between New Zealand Maoris and Hawaiian Polynesians showed similarities in terms of hypertension, obesity, and diabetes but gout was uncommon in the Hawaiians and uric acid levels were significantly lower than in Maoris (Healey et al., 1966). This suggests that not all Polynesian groups have the same measure of genetic predisposition to hyperuricaemia. These differences have not as yet been explained.

Progress must now be made with early recognition and intervention in subjects at high risk. Weight reduction and supervised long-term drug therapy will be the cornerstones of this approach.

Further population studies can be justified when undertaken to identify the distribution of SUA and gout with a view to exploring basic mechanisms, particularly those involving body composition and blood pressure. This would include sub-sampling males and females at different SUA levels to measure urate binding and other metabolic pathways.

This work was supported by grants to the Wellington Hospital Epidemiology Unit from the Medical Research Council of New Zealand and from the World Health Organisation. We wish to acknowledge the help of Drs P. J. Hatfield and B. L. J. Treadwell who gave advice and criticism. The work of the survey team and the help of the Maori people who took part in the surveys is especially acknowledged.

\section{References}

Abell, L. L., Levy, B. B., Brodie, B. B., and Kendall, F. E. (1952). A simplified method for the estimation of total cholesterol in serum and demonstration of its specificity. Journal of Biological Chemistry, 195, 357-366. 
Buchanan, M. J., Isdale, I. C., and Rose, B. S. (1965). Serum uric acid estimation. Annals of the Rheumatic Diseases, 24, 285-288.

Campion, D. S., Olsen, R., Bluestone, R., and Klinenberg, J. R. (1975). Binding of urate by serum proteins. Arthritis and Rheumatism, 18, 747-750.

Frisancho, A. R. (1974). Triceps skinfold and upper arm muscle size norms for assessment of nutritional status. The American Journal of Clinical Nutrition, 27, 10521058.

Gertler, M. M., Garn, S. M. and Levine, S. A. (1951). Serum uric acid in relation to age and physique in health and in coronary heart disease. Annals of Internal Medicine, 34, 1421-1431.

Hall, A. P., Barry, P. E., Dawber, T. R., and McNamara, P. M. (1967). Epidemiology of gout and hyperuricemia. American Journal of Medicine, 42, 27-37.

Healey, L. A., Caner, J. E. Z., Bassett, D. R., and Decker, J. L. (1966). Serum uric acid and obesity in Hawaiians. Journal of the American Medical Association, 196, 364-365.

Jelliffe, D. B. (1966). The Assessment of the Nutritional Status of the Community. WHO Monograph Ser. 53. Geneva.

Kennedy, A. C., Brennan, J., Anderson, J., Brooks, P., Buchanan, W. W., and Dick, W. C. (1975). Serum uric acid-its relationship to lean body mass, sex, plasma urea, intracellular potassium and packed cell volume in a normal population group. Annals of the Rheumatic Diseases, 34, 543. Abstract of paper presented to the Heberden Society in March 1975.

Lennane, G. A. Q., Rose, B. S., and Isdale, I. C. (1960).
Gout in the Maori. Annals of the Rheumatic Diseases, 120-125.

Mikkelsen, W. M., Dodge, H. J., and Valkenburg, H. (196 The distribution of serum uric acid values in a populatign unselected as to gout or hyperuricemia. American Jouraal of Medicine, 39, 242-251.

Prior, I. A. M. (1962). A health survey in a rural Maß; community. New Zealand Medical Journal, 61, 333-388.

Prior, I. A. M., and Rose, B. S. (1966). Uric acid, gout and public health in the South Pacific. New Zealand Medicral Journal, 65, 295-300.

Prior, I. A. M., Rose, B. S., Harvey, H. P. B., and Davidson, F. (1966). Hyperuricaemia, gout, and diabetic abnormality in Polynesian people. Lancet, 1, 333-338.

Rose, B. S., Prior, I. A. M., and Davidson, F. (1966). Gक्षit and hyperuricemia in New Zealand and Polynesia. $\overline{\mathrm{S}}$. Proceedings of the Third International Symposium cof Population Studies in the Rheumatic Diseases, Ch. 45, pp. 344-353. Excerpta Medica, International Congress Series No. 148: New York.

Sheldon, W. H., Stevens, S. S., and Tucker, W. B. (1949). The Varieties of Human Physique, 1st ed. Harper: NGw York.

Snaith, M. L., and Coomes, E. N. (1977). Gout with normeal serum urate concentration. British Medical Journal, 으, 685-686.

Sturge, R. A., Scott, J. T., Kennedy, A. C., Hart, D. P., aød Buchanan, W. W. (1977). Serum uric acid in England and Scotland. Annals of the Rheumatic Diseases, 36, 420-420.

Sunderman, F. W., Jr. (1975). Current concepts of 'normal values,' 'reference values,' and 'discrimination values' in clinical chemistry. Clinical Chemistry, 21, 1873-1877. 